\title{
JEWISH IMMIGRANT FOODWAYS: HYPHENATING AMERICA
}

\author{
Nadia Faradhillah \\ nadiafaradhillah@gmail.com
}

\begin{abstract}
The article's purpose is to examine the significance of Kosher Laws in Jewish foodways as religious and cultural signifier for Jews' identity. Besides, this article also aims to explain the way the Jewish immigrants assimilate with American culture through their foodways. This topic is chosen because Jewish immigrants have unique position in American society in accordance with their food way. In the "New Land" that guarantees them freedom they struggle to keep their identity and assimilate as religious and cultural group through Jewish foodways.

Qualitative method is used in this library research on Jewish foodways archives and writings. This article is started by introduction portraying Jews migration to the United States and their foodways that they brought along the migration.

The findings of this research show that Jewish foodways divided the Jews for the difference of opinion between the Jews towards their Kosher Laws. The non-religious Jews adapt easily to the American foodways. The religious Jews find it difficult to assimilate to the American foodways. However, they find a way to assimilate and still keep their obedience.
\end{abstract}

Keywords: Kosher Law, Jewish American, Theory of Practice, Post-Nationalism, Foodways

\section{Introduction}

Since the very first time the New Land was found, people are attracted to migrate to the New Land with diverse of reason. The immigrants mostly seek for better life, political freedom from governmental tyranny, and religious freedom. The Jews are one of the ethnical groups that migrate to seek for better life and religious freedom. They entered America in 1654 through New York and settled there (Deutsch and Saks, 2008: 14). This is the reason why New York has so many Jewish communities. The Jewish immigrants landed in New York and the other costal cities, such as New Port, Rhode Island, Savannah, and Georgia because the boats that they sailed on departed for those cities. However, not until 1830s-1840s, the first large wave of Jews immigrants enters United States and the second wave entered in 1860s continued until twentieth century (Deutsch and Saks, 2008: 15). The number of Jewish immigrants reaches its highest point when World War I and II occurred. So many Jews fled to the United States since they underwent unpleasant political condition in Germany and other Eastern 
European countries (Deutsch and Saks, 2008: 16).

The common Jewish immigrants come to United States are the typically poor and low funded people that seek a chance to get better life. Fortunately, Jewish has strong ethnical bound so that the Jewish immigrants that had already settled in the United States will help the newly arrived Jews to start a new life in America. With the help of the Jewish community, the newly arrived Jews found occupations and start to earn a living. The occupations they had in the United States are something they are prohibited to do in their home country before the migration, such as doctor, lecturer, and business. Through the job, they are able to move to a higher social class. That change results in the abundance of food that they can afford (Diner, 2002: 179-180).

Food is the form of culture that is produced by a certain ethnical group. When an ethnic group migrates to any different area, they will bring the foodways with them to the new place. However, the condition in the new place will be very different from the former place. In the new place, everything is unsettled and it makes the group difficult in fulfilling their needs of food that suits their foodways. Hence, they need to adapt their foodways by seeking the complementary food that is similar to the food that they used to consume in daily basis (Almerico, 2014: 3).

Caplan in Mintz and Du Bois states that as the form of material culture, food serves ambivalence function which unites the group or destroys the group (2002: 109). The function of food which unites the group is shown in the Javanese's attitude that frequently offers other people to eat to show their compassion towards certain people. It is because the Javanese are not taught to say 'I love you' to express their love to other people. On the other hand, the function of food that destroys the group is when the food becomes the source of wars or that the food is defined as class identification.

Food is also used to determine the identity which relates to ethnicity, gender, race, and nationality. Nonetheless, Murcot states that the idea of identity itself is merely human imagination. In other words, Murcot wants to say that identity is socially constructed in people's mind and is embraced by the society as values (Mintz and Du Bois, 2002: 109). Hence, every aspect within the society is also socially constructed and just human imagination, including foodways. For instance is the idea of rice as primary food 
to many Indonesians. There is a belief in Indonesians that they are not considered eating if they do not eat rice, even when they eat another form of carbohydrate, such as bread, corn, or potato. This idea is rooted deeply in Indonesians mind and builds the Indonesian identity through foodways. It is proven when the Indonesians go abroad, they will find a way to get the access to rice to eat even the type of rice that they get will be totally different to the rice that they usually eat in Indonesia, they will still eat it.

The Jews should adapt themselves in term of foodways since they had been lived in poor condition and face the scarcity of food. Moreover, they also have to adapt to the multi-cultural condition in the United States. The United Sates consists of so many immigrants that come from different ethnical group and historical background and each of the ethnical group brings their culture including foodways. As a result, the United States provide abundant types of ethnical food that are brought by the immigrant. Facing this condition, the Jews are difficult in balancing their religious and secular life. The difficulties are harder when it comes to the subject of foodways since the Jews has dietary laws that should be observed.
Because of the foodways, the Jews develop such a paradoxical position. The paradoxical position puts them between the obligation to be observant to Jewish dietary laws and the desire to connect to American life-style and society. On the other hand, the paradoxical position owned by the Jews is also depicted in these research questions: What is the significance of Kosher laws in defining Jews identity in the United States? and How the Jews assimilate with American foodways?

\section{Methodology}

Qualitative method is used in this research in order to get the interpretation of American Jewish identity and their foodways. Qualitative method is a way to cover the meaning of human beings, both as an individual or a member of a group through the problems exist in the society (Creswell, 2009: 1). The approach, moreover, is Post-Nationalism in American Studies as Rowe argued that this approach is based on varied culture and ethnic in the United States influence the intersection and interaction among American society. This approach surges as the counter-thesis of American Exceptionalism that has been dominating the course in American Studies. Post- 
Nationalism approach emerge as a result of the immigration waves came to the United States which reform American society and create cultural hybrid in the society of Americans (2000: 24).

The research will go through two steps, namely, collecting data and analyzing data. As it takes the form of library research, thus, the collecting data process will concern to the study on books and articles about Jewish American foodways. Then, the data will be analyzed by theory of practice. The theory of practice constitutes routine activities which involve some elements that interconnect to one another that can result as bodily activities, "stuff" and its function in life, mental, emotion, beliefs, and knowledge (Reckwitz in Warde, 2005: 133). The theory of practice will be used to interpret the data to answer the research question.

\section{Discussion}

As what Reckwitz mentions that the routine activities done by human beings will produce belief. Jews is either ethnical group or religious group. It means that Jews do not only practice the cultural tradition but also obligate to observe some religious laws. Nevertheless, some people, outsider mostly, will interchange the meaning of Jewish cultural tradition and religious observance. This is for the reason that there is lack of understanding the Jews as ethnical group and the Jews as religious group. One of the aspects that are frequently misunderstood by some outsider is the Kosher laws for Jews as religious group. The practice of Kosher laws has become the routine of the Jews long before they migrate to the United States. It has been in the Jews mindset that one of the deals for being a Jew is observing the Kosher laws. Supported by the issue of health and holiness, the practice turns into something that they must oblige and believe. The Kosher laws contain the regulation of anything that should and should not be eaten by the Jews (Deutsch and Saks, 2008: 105-106). For example, the regulation that prohibits the Jews from eating the derivation of meat swine and the regulation that prohibits them for eating meat and diary product at the same time. Kosher laws, furthermore, is the laws that arrange Jewish foodways, which according to Warde, cooking and foodways are included to the integrative practice. The term integrative practice means that the actions or activities done by human beings consist of complex structure because it contains all the three elements in the practice's interconnection; 
understanding, rigid rules, and 'teleoaffective' which regarded as beliefs and emotions stuff (2005: 134-135). Warde, moreover, argues that when the three aspect of the practice's interconnection is met, which he also said to be an unusual case, it will be hard to change the practice (2005: 136).

From the beginning of their immigration to the United States, they face the difficulties to find food that in accordance with Kosher. Although the United States provide so many kinds of food that they can eat, they still have the difficulties to find Kosher. They realize that their dietary laws limit them in adapting and assimilating with America. Nonetheless, they still tenaciously observe the Kosher laws. For the Jewish Americans who live far away from the city with so many Jewish communities where provides the complete facilities to the Jews like New York or Port Chester, they have to buy the Kosher food from there or send a courier to buy them the Kosher food (Diner, 2002: 182).

The change of practice that had been lasted for a long time, nonetheless, is possible to occur since human beings as an individual and a member of the society will adapt themselves to the change of their surroundings (Warde, 2005: 136).
With the emerging multicultural society, soon, Jewish Americans notice the gap in their Jewishness and Americanness. Leaving their home country for more religious freedom, they feel alienation from their Jewishness to their Americanness. It seems that the Jewishness can not accommodate the religious freedom they longed even if the freedom is in front of their eyes. Because of this, some Jewish Americans start to think about their dietary laws and its applicability in the United States. Arguably, one of the reasons that they come to the United States is for religious freedom. They think that their migration will be in vain if they are still limited by the religious regulation. Therefore, as what Diner denotes that the Jewish American start questioning the significance of Kosher laws. Some of them think that by being observant to the Kosher laws restrict them to feel mainstream American experience which prevents the formation of their identity as Jewish-American. As a result, this type of Jewish American renegotiates the Kosher laws by themselves, and they become more flexible in assimilating and embracing mainstream American experience (2002: 184). It is seen that these Jewish Americans consider that their 
"Jewishness" is descent from the ancestors. The Jewishness is not defined by the Jewish religious regulation like the Kosher laws. Moreover, as an immigrant they hyphenate their Jewishness to mainstream American experience and culture so that they can embrace the new identity as an American.

At the same time, the other group of Jewish Americans criss-crossing to the former group regards that religious laws are something that should be embraced and observed whenever and wherever they are to underline their identity as Jews (Diner, 2002: 180-181). Thus, the version of Jewishness according to this group is that the observance to the religious laws that makes them Jews. The Jewishness is not merely determined the ancestry but it is and should be determined by the values that is embraced by the people in the daily basis. Sticking to the Kosher laws is one of the embodiments of the Jewishness.

These different opinions and perspectives of foodways and dietary laws emerge dispute between the Jewish immigrants in the United States. Hence, this difference split the Jewish immigrants in to four groups (Deutsch and Saks, 2008: $\mathrm{x})$. The first group is religious traditional Jews. Religious traditional Jews can be said as the orthodox Jews because they stick to both cultural values and religious regulation to define their identity as Jews. Moreover, they regard that cultural values and religious regulation can not be shoved aside merely for migration and new culture. The second type group is called religious non-traditional. This people stick to religious regulation, but they also enjoy and embrace the other aspect of mainstream American experience. For example, they still observe Kosher laws and attend the synagogue, but they also have after work hangout to Kosher pizzeria. The third type of Jews is nonreligious traditional. The people of this group practice the cultural values of Jewish culture, but they leave the religious practice and observance out of their daily basis. For instance these people will still attend the Jewish holiday, speaks in Hebrew, or, eat and cook Jewish food, but they do not observe Kosher laws or attend the Jewish religious rituals like synagogue. The last type of group is called nonreligious non-traditional. They consider themselves as Jews by ancestry because they neither practice Jewish cultural values nor observe Jewish religious laws, especially in the case of foodways. They practically eat the same food as the Americans have in their area. 
The food and foodways is proven to emerge dispute between the Jewish Americans so that they are grouped base on their observance to Kosher laws. For non-religious groups (non-religious traditional and non-religious nontraditional), the Jewish Americans who practically left the Kosher laws out of their daily basis, so that they will not be bothered by the food that they consume are in accordance to the Kosher laws or not. They immediately embrace the mainstream American culture and experience. They easily assimilate to other ethnical group and do not have major difficulties to socialize with them. This is one of the ways that the Jews from these groups used to define their JewishAmericans identity, by not observing either one or both Jewish cultural and religious values. However, at some point, they will still attend the Jewish holiday with their family and they will automatically eat Kosher food or Kosherstyle food (Deutsch and Saks, 2008: x).

On the other hand, the religious group (non-traditional religious and traditional religious) face more difficulties in assimilating with the society. In the case of food and foodways, they seem to be pickier to food than the average Americans. It is for the reason that they have to consider the Kosher laws that they observed and be careful to whatever they wanted to eat. It is harder when they have to eat with non-Jews friends or acquaintances because they face such a paradoxical situation, one that anchor them to obey the Kosher laws and the other that capture their urge for not hurting their friends' feelings. They sometimes should also face the awkward situations such as having matzah in lunch time for Passover when the other children in the class have original bread (Deutsch and Saks, 2008: 22). It may be practically not assaulting or discriminating but it reminds the Jewish Americans that they are Jews and not fully embrace the mainstream American culture and experience.

It is stated that the non-religious group face less difficulties in choosing their food because they do not have to worry about the Kosher laws. Thus, it provides them with the abundance of food and foodways that they can get in the United States. As for the religious group, time emerge the desire to connect with mainstream American culture and experience, but they face harder fact that they is observant towards the Kosher laws to keep their Jewish identity. Thus, as the time rolls by the religious group try to balance their Jewish and American identity. 
In the scope of food and foodways they reinvent the typically American food or other ethnical food that suit their Kosher laws by replacing or complementing any foodstuffs that do not go along with the Kosher laws to foodstuffs that suit to the Kosher laws (Deutsch and Saks, 2008: 49).

Kosher laws prohibit them for eating any meat produced without religious propriety and product that is derived from meat swine. Despite most of the meat product provided in the United States is made without any Jewish religious propriety, and some of the meat products are made of the derivation of swine, the desire to taste the mainstream American culture and experience through food emerge between the religious Jewish Americans. They find the way to compromise their desire to American experience and the Kosher laws by complementing all the meats with the meats that suit to the Kosher laws (Deutsch and Saks, 2008: 50). Moreover, the Kosher laws state that the Jews are prohibited to eat meat products and dairy products at the same time. For instance, the Jews are not able to eat cheeseburger, or have dessert after having the main course contains meat products. However, they will loose themselves and complement either meat or diary product with 'fake meat' or 'soy (made for vegetarians) diary' so that the food will go along with the Kosher laws (Deutsch and Saks, 2008: 51).

The Jews will usually replace the cheese in cheeseburger with soy cheese. When they make mashed potato to be eaten with steak, they will complement butter and milk in the mashed potato with margarine and soy milk (Deutsch and Saks, 2008: 51). The complementary used should not change the taste of the food, so that they will still have the similar taste although the taste is not completely the same as the authentic food. The Jews are also interested in ethnical food, such as Chinese, Italians, and Mexicans (Deutsch and Saks, 2008: 50). The spaghetti made by the Jews use soy meat or 'fake meat' to complement bacon. While, the Chinese fried rice will use Kosher meat and 'fake shrimp'. The Jews interest towards Chinese food is so great that there are so many Kosher Chinese products are produced. Moreover, seeing this opportunity, the Chinese open Chinese restaurant near the Jewish community and provide them with Chinese food that is cooked by Kosher-style.

In term of the adapting food, the religious Jewish Americans are benefited by vegetarian life-style that invents soy- 
based food industry that compromises the Kosher laws for the Jewish American. Through the adapting food, religious Jewish Americans can also invent their own mainstream American culture and experience. The adapting food also makes them possible to assimilate with the other foodways like Chinese, Italians, and Mexicans. Adapting food reform their identity as Jewish-Americans that permit them to embrace the American culture and experience through food and foodways and keep their Jewishness by observing the Kosher laws.

\section{Conclusion}

It can be concluded that the migration to the United States makes the Jewish questioning their dietary laws that are considered to restrict them to mingle in American society. Some of the Jews decide to leave the Kosher laws behind and follow the mainstream American culture and experience. This action immediately reforms their Jewish identity.

Furthermore, he dispute of Kosher laws in Jewish community in the United States split the Jews in to two major groups, the religious and the non-religious. The former group that leave the Kosher laws behind face less difficulty than the religious ones since they regard their
Jewishness is descended by their ancestry. The different fate should be faced by the religious Jews because they have to feel the dilemma to choose their observance to the Kosher laws or the desire to experience American culture. This group considers that their Jewishness is determined by their observance to the Jewish religious laws, such as Kosher laws. However, adapting food solve the religious Jews problem by complementing the non-Kosher food to Kosher food. At this rate, the practice of Kosher laws that firstly indicate will be hard to change, adapt to the socio-cultural surroundings of the United States' multicultural society. Thus, it allows the Jews, especially the religious group, to embrace both their Jewish and American identity.

\section{References}

Almerico, Gina M. 2014. "Food and Identity: Food Studies, Cultural, and Personal Identity.” Journal of International Business and Cultural Studies 1-7.

Creswell, John W. 2009. Research Design Qualitative, Quantitative, and Mixed Method. Los Angeles: Sage Publication.

Deutsch, Jonathan and Saks, Rachel D. 2008. Jewish American Food Culture. Westport: Greenwood Press. 
RUBIKON Volume 4 / Number 1

February 2017

Diner, Haisa R. 2002. Hungering for America: Italian, Irish, and Jewish Foodways in the Age of Migration. Cambridge: Harvard University Press.

Dresner, Samuel H. 1966. The Jewish Dietary Laws: Their Meaning for Our Time. New York: The Burning Bush Press.

Mintz, Sidney W. and Du Bois, Christine M. 2002. "The Anthropology of the Food and Eating." Annual Reviews Anthropology 99-119.

Rowe, John Carlos. 2000. Post-nationalist American Studies. California: University of California Press.

Warde, Alan. 2005. "Consumption and Theories of Practice." Journal of Consumer Culture 131-153. 